\title{
Mirosław Jankowiak
}

Instytut Slawistyki Polskiej Akademii Nauk

Warszawa

\section{Leksyka pochodzenia bałtyckiego w mieszanych białorusko-rosyjskich gwarach południowej Pskowszczyzny (rejon Siebieża i Newla)}

\section{Wprowadzenie}

Przedmiotem opisu w tym artykule jest słownictwo pochodzenia bałtyckiego, funkcjonujące we współczesnych gwarach rejonu siebieskiego i newelskiego południowej Pskowszczyzny ${ }^{1}$ wchodzącej obecnie w skład Federacji Rosyjskiej. Gwary na badanym obszarze, zaliczane wcześniej do białoruskich, mają obecnie charakter mieszany, białorusko-rosyjski. Obszar ten od setek lat był miejscem kontaktu różnych języków, kultur, grup etnicznych / narodów i wyznań. Mieszkający tutaj Bałtowie, Białorusini, Polacy, Rosjanie i Żydzi posługiwali się białoruszczyzną, polszczyzną, językiem rosyjskim lub jidysz i reprezentowali różne wyznania: katolicyzm, prawosławie (oraz starowierstwo), wyznanie greckokatolickie i judaizm. Taka mozaika narodowościowa bardzo mocno wpływała na strukturę języka miejscowej ludności, co widoczne jest do dzisiaj także w leksyce.

Podstawą do analizy jest materiał pochodzący z dwóch źródeł. Pierwsze źródło to Regionalny słownik pskowski (ПOC, 1967-), ukazujący leksykę zbieraną w trakcie badań dialektologicznych od $1952 \mathrm{r}$. Tom pierwszy został wydany w 1967 r., a prace nad kolejnymi

\footnotetext{
${ }^{1}$ W tym artykule pod pojęciem południowa Pskowszczyzna będę rozumiał jej współczesne granice administracyjnie, a nie historycznie. 
trwają do dzisiaj. Ostatni tom 26 kończy się na literę P (do hasła nнymb). Dla autorów punktem wyjścia nie były jednak ziemie historycznej Pskowszczyzny (czyli obszar występowania pskowskiej grupy gwar), lecz obecne granice administracyjne (obwód pskowski). W ten sposób słownik uwzględnia materiał z terenów wchodzących niegdyś w skład Wielkiego Księstwa Litewskiego (dalej WKL), Rzeczypospolitej i guberni witebskiej. Już wstępna analiza leksyki w nim zamieszczonej ujawnia jej mieszany białorusko-rosyjski charakter oraz liczne zapożyczenia, przede wszystkim bałtyckie, nieco mniej polskich.

Drugim podstawowym źródłem do analizy są materiały własne zebrane przeze mnie w trakcie ekspedycji letniej w 2014 r. Objęła ona dwa rejony - siebieski i newelski, a została sfinansowana i przeprowadzona w ramach międzynarodowego projektu TriMCo (Triangulation Approach for Modelling Convergence with a High Zoom-In Factor), kierowanego przez prof. Björna Wiemera z Instytutu Slawistyki Uniwersytetu J. Gutenberga w Moguncji. Celem projektu jest ukazanie procesów konwergencyjnych - wariantywności cech dialektalnych i wzajemnego przenikania się języków (bałtyckich, słowiańskich, fińskich) na różnych poziomach struktury języka na pograniczu białorusko-bałtyckim²

Badania terenowe zostały przeprowadzone przeze mnie w następujących miejscowościach rejonu siebieskiego (łącznie 5 h 20 min nagrań):

- gmina Sosnowy Bór (волость Сосновый Бор, 3109 mieszkańców w 2015 r.), położona na zachód od Siebieża, przy granicy z Łotwą i Białorusią, wieś Zasitino (Заситино);

- gmina Maksiutino (волость Максютино, 448 mieszkańców w 2015 r.), położona na północny wschód od Siebieża, wsie: Kazichi (Козихи), Kickowo (Кицково);

- gmina Bojarinowo (Бояриновская волость, 416 mieszkańców w 2015 r.), położona w południowo-wschodniej części rejonu, wieś: Bojarinowo (Бояриново);

- gmina Krasnoarmiejska (Красноармейская волость, 317 mieszkańców w 2015 r.), położona na wschód od Siebieża, wieś: Połozowo (Полозово).

W rejonie newelskim badałem następujące gminy (łącznie 9 h 40 min nagrań):

- gmina Ust'-Dołysy (Усть-Долысская волость, 1495 mieszkańców w 2010 r.) położona na północny zachód od Newla, wsie: Iwancewo (Іванцево), Kanaszowo / ob. Czerniecowo (Канашово / Чернецово), Ust'-Dołysy (Усть-Долыссы);

- gmina Golubojezierska (Голубоозерская волость, 1058 mieszkańców w 2010 r.) położona na północny wschód od Newla, wsie: Spass-Bałazdyń (Спасc-Балаздынь), Opuchliki (Опухлики);

- gmina Nowochowańsk (Новохованская волость, 660 mieszkańców w 2010 r.), wieś: Nowochowańsk (Новохованск);

- miasteczko Newel (Невель, 15417 mieszkańców w 2014 r.).

\footnotetext{
${ }^{2}$ Więcej informacji o projekcie znajduje się na stronie internetowej: http://www.trimco.uni-mainz.de/
} 
Zgodnie z przyjętymi w dialektologii zasadami, wywiady zostały przeprowadzone z osobami najstarszego pokolenia, które nie opuszczały na dłużej swojej miejscowości lub przemieszczały się tylko w obrębie gminy lub rejonu.

\section{Specyfika gwar południowej Pskowszczyzny}

Obszar rejonu siebieskiego i newelskiego historycznie zaliczany był do białoruskojęzycznego, co potwierdzają liczne prace badaczy okresu przedrewolucyjnego, zarówno etnografów, jak i lingwistów. Różne mapy, ukazujące etnograficzny zasięg etnosu białoruskiego z przełomu XIX i XX w., opracowywano głównie na podstawie kryterium lingwistycznego. Widać na nich, że ziemie zamieszkane przez Białorusinów zdaniem badaczy w dużym stopniu pokrywają się z dawnymi granicami WKL i Rzeczypospolitej, jak np. na Etnograficznej mapie Rosji europejskiej z 1875 r., opracowanej przez Aleksandra Ritticha (Риттих, 1875), czy Etnograficznej mapie białoruskiego plemienia Joachima Karskiego (Карский, 1903). Również członkowie Moskiewskiej Komisji Dialektologicznej w swoim ujęciu kartograficznym Próba mapy dialektologicznej języka rosyjskiego w Europie, zaliczyli ziemie powiatu newelskiego i siebieskiego do obszaru białoruskojęzyсznego (Дурново, Соколов, \& Ушаков, 1915, s. 4). Białoruski charakter analizowanych gwar potwierdzał także Piotr Buzuk podczas ekspedycji do powiatów newelskiego i wielkołuckiego w 1926 r. (Бузук, 1926). Jeszcze w pierwszych latach po II wojnie światowej radzieccy dialektolodzy interesujący nas obszar zaliczali do białoruskojęzycznego, co ukazuje np. Mapa dialektologiczna języków wschodnioeuropejskich (Диалектологчческая карта восточноевропейских языков), opracowana przez Rubena Awaniesowa (Аванесов, 1949).

Od lat 60. XX w. południowa część obwodu pskowskiego, podobnie jak zachodnia Smoleńszczyzna i zachodnia Briańszczyzna, traktowane są w rosyjskim językoznawstwie jako obszar rosyjskojęzyczny, co ukazuje Dialektologiczna mapa języka rosyjskiego (Диалектологическая карта русского языка), opracowana przez Kapitolinę Zacharową i Warwarę Orłową (Захарова \& Орлова, 1970). Gwary rejonu siebieskiego i newelskiego są zakwalifikowane obecnie jako grupa zachodnia południowego narzecza języka rosyjskiego (Колесов, 2006, ss. 36, 37; Касаткин, 2005, s. 184). Symboliczną granicą zasięgu występowania gwar białoruskich i rosyjskich stała się zatem granica administracyjna między Białorusią a Federacją Rosyjską.

Z moich obserwacji wynika, że gwary okolic Siebieża i Newla należy uznać za mieszane (w przeszłości przejściowe) ${ }^{3}$, rosyjsko-białoruskie, przy czym przeważa zdecydowanie leksyka rosyjska. Jednak słów białoruskiego pochodzenia zachowało się do dzisiaj bardzo wiele, co nie dziwi ze względu na uwarunkowania historyczne. W innym artykule (Jankowiak, 2015, s.226) przytaczam ich ponad 60, co stanowi zaledwie ich

\footnotetext{
${ }^{3}$ W rozumieniu tych terminów, zaproponowanym przez Elżbietę Smułkową (Smułkowa, 2002).
} 
niewielką część. Są to zarówno polonizmy, które w większości przypadków trafiły do mowy miejscowej ludności za pośrednictwem białoruskim (agrest 'agrest', batjan 'bocian', bawełna 'bawełna', wygliad 'wygląd', widelce 'łyżka stołowa, widelec' (zob. Grek-Pabisowa, 1986), jak i słowa typowo białoruskie: baćka 'ojciec', $d y k$ 'ot', niczoha 'nic, niczego', jana 'ona' i in. (zob. Jankowiak, 2015, s. 226). Do niedawna można było jeszcze usłyszeć w wypowiedziach mieszkańców Newla żydowskiego pochodzenia takie słowa, jak np.: aufn dach (ауфнн даx) 'na dachu', końkies (конькес) 'łyżwy', buraczkis (бурачкис) 'buraki', Srul' (Сруль) 'imię żydowskie Srul; tutaj: wulg. ubrudzone dziecko, obsraniec'4. Jak widać, niektóre z nich trafiły do jidysz z języka polskiego i / lub białoruskiego.

W większości przypadków miejscowa ludność nazywa swój język bądź rosyjskim, bądź „zmieszanym”. Choć użytkownicy zachowują często cechy fonetyczne i gramatyczne gwary białoruskiej, to jednak z powodu stopnia nasycenia swojej mowy leksyką rosyjską, oceniają ją ogólnie jako rosyjską.

U mienia ruskij, u nas wsiech ruskij jazyk, my wsie ruskije [K 1932, Spas-Bałazdyń, RU];

Toka na ruskam [rozmawiamy], ździeś wsio tak, no, bywajet akcent takoj, sam zamiecisz, szto eta nia czista ruskij, ruskij s chachtom, ruskij sjewriejam, ad paliakau oczień mnoha uziali [słów] [K 1925, Opuchliki, RU].

\section{Leksyka pochodzenia bałtyckiego}

Obszar południowej Pskowszczyzny był zamieszkiwany najprawdopodobniej przez ludy bałtyckie i fińskie, które żyły na o wiele większym obszarze niż obecnie. Zachowane do dzisiaj hydronimy bałtofińskiego pochodzenia (także na terytorium obwodu pskowskiego) wskazują na ogromny obszar zamieszkany przez te niesłowiańskie ludy, a sięgający od Morza Bałtyckiego po Prypeć na południu, dorzecze górnej Wołgi i Oki na wschodzie i dolinę Dzisny na północy. Potwierdzają to badania wielu wybitnych językoznawców, m.in. L. Bednarczuka, A. Vanagasa, Z. Zinkevičiusa i in. (Bednarczuk, 2010, ss. 166-180; Ванагас, 1983; Zinkevičius, 1998, s. 12). Z czasem ziemie te zaczęły zajmować ludy słowiańskie a obecna granica pomiędzy Bałtami a Słowianami ustaliła się zapewne w VII-XVIII w. ${ }^{5}$

Zarówno starsze, jak i najnowsze spisy ludności (Данные Всероссийской переписи, 2004; Tichomirow, 2005) nie wykazują na terytorium rejonu siebieskiego i newelskiego

${ }^{4}$ Na podstawie rozmowy z Ludmiłą Maksimowską (pochodzenia żydowskiego), dyrektor Muzeum w Newlu, czerwiec 2015 r.

${ }^{5}$ Kwestia chronologii slawizacji dawnych ziem bałtyckich w tym okresie ciągle jest dyskusyjna, a wyniki badań lingwistów z Polski, Białorusi i Litwy nierzadko znacząco od siebie odbiegają. Np. litewski językoznawca Zigmas Zinkevičius uważa, że ekspansja słowiańska na ziemiach litewskich odbywała się później, w VIII-XIV w. i nie miała masowego charakteru. 
osób pochodzenia litewskiego lub łotewskiego (wyjątek stanowiło na przykład Abrene, obecnie Pytałowo, należące przed wojną do Łotwy ${ }^{6}$ ). Nie oznacza to jednak, że nie było żadnych kontaktów ludności z Pskowszczyzny z Bałtami. Z wyjątkiem okresu międzywojennego, kiedy granica była bardzo dobrze strzeżona, ludność dość swobodnie przemieszczała się, zarówno przed I wojną światową, jak i w czasach ZSRR. Dowodzą tego moje liczne rozmowy z miejscową ludnością, zarówno z rejonu siebieskiego i newelskiego, jak i po stronie łotewskiej (Zilupe, Posiń). Wiele osób z rosyjskiej strony wyjeżdżało do pracy na kilka, a czasem kilkanaście lat do kołchozów i sowchozów Łotewskiej SRR i Litewskiej SRR (gdzie były lepsze zarobki i wyższy standard życia), nierzadko też po II wojnie światowej przybywali tam w poszukiwaniu schronienia i żywności:

A siena my zdawali, wazili u Łatwiju, i Ziłupu, w Ziłupu siena wazili [...] tam prinimali siena, to uże pos'lie wajny, u nas był kałchoz „Wpieriod". U nas wsio pa tałonam, wodka, pa tałonam, sachar, a u Łatwii usio swabodna było, tri raza w dzień awtobus iszot, a tiepier' [po rozpadzie ZSRR] k nam Łatwija jezdzit, stuszaj, stoka Łatyszej. Wsie pradukty u nas, a u nich ukusniej [smaczniejsze], a u nas padzieszewlie, i bienzin i usio [K 1941, Zasitino, RU];

[po wojnie] $z$ Rasii chadzili bol'sze, nu prasili usio, szto tam usio spaliena było [na Siebieżczyźnie], prychadzili, my ich, eta, pumahali, pumahali, dawali naczawać, ili jady [jedzenia], ili adzioż $i$ szto była to dawali [K 1928, Posiń, LV].

Z kolei obywatele Łotewskiej SSR i obecnie Łotwy prowadzą interesy po stronie Federacji Rosyjskiej (częściej Siebież, rzadziej Newel). Kwitnie również handel przygraniczny, Łotysze kupują m.in. tańszą benzynę, papierosy i artykuły spożywcze, a Rosjanie np. sprzęt gospodarstwa domowego czy RTV.

Leksyka pochodzenia bałtyckiego należy zazwyczaj do starszej warstwy słownictwa i dotyczy tradycyjnej uprawy roli, otaczającej przyrody, życia codziennego mieszkańców czy cech charakteru i wyglądu człowieka. Wiele z tych słów zostało zapożyczonych już dawno temu do gwar białoruskich czy polszczyzny północnokresowej (zob. np. Turska, 1982; Rutkowska, 2014, 2015), co wpłynęło niewątpliwie na zachowanie tych leksemów na południowej Pskowszczyźnie do dzisiaj. Ze względu na uwarunkowania historyczne i dawną specyfikę analizowanych gwar (tj. ich białoruski charakter w przeszłości) większy nacisk przy analizie bałtyzmów będę kładł na źródła dotyczące białoruszczyzny. Do języka starobiałoruskiego, kancelaryjnego oraz gwar, trafiały one już w czasach WKL, czego dowodzą chociażby zabytki piśmiennictwa pochodzącego nawet z XIV w. Na przykład Aliaksandr Bułyka doliczył się ponad 50 leksemów litewskiego pochodzenia, które weszły do białoruszczyzny w okresie od XIV do XVIII w.

${ }^{6}$ W 1935 r. Łotysze stanowili w tym rejonie prawie 55\%, a obecnie zamieszkuje tu tylko ok. 70 osób, co stanowi poniżej $1 \%$. 
(Булыка, 2015, s. 166). Już ponad 100 lat temu Joachim Karski (Карский, 1962) wskazał prawie 90 leksemów bałtyckiego pochodzenia w gwarach białoruskich na terenach przylegających do Litwy i Łotwy. Z drugiej strony zachowaniu leksyki bałtyckiego pochodzenia na południowej Pskowszczyźnie sprzyja występowanie analogicznych leksemów w języku ogólnorosyjskim, np.: dezoms 'dziegieć, smoła', скupдa 'stóg zboża, słomy, siana', ковш 'czerpak do płynów w kształcie szerokiego kubka z uszkiem', ендова 'dzban z dziobkiem', кувщи 'wysoki dzban do przechowywania napojów', пелька 'przerębel, nieduży zbiornik wody; błotniste miejsce na polu, w lesie', янтарь 'bursztyn' i in. (zob. Лаучюте, 2007, s. 32).

Badania nad leksyką bałtyckiego pochodzenia na pograniczu białorusko-łotewsko-rosyjskim były prowadzone przez wielu badaczy, jak np.: Jūratė Laučiūtė (Лаучюте, 1971, 1982, 2007), Benita Laumane (Лаумане, 1974), Joachim Karski (Карский, 1962) i in. Ich publikacje opierają się jednak na materiałach zebranych kilkadziesiąt lat temu.

Poniżej przytaczam wybrane leksemy, wyekscerpowane z Regionalnego słownika pskowskiego (ПОС) i / lub pochodzące z materiałów własnych:

Aświerr - 'żuraw studzienny’, lit. svir̃tis i łot. svira, svēre ‘żuraw studzienny’, słowo zaliczone przez J. Laučiūte do bałtyzmów w językach słowiańskich (Лаучюте, 1971, s. 78, 1982, s. 52). Autorzy ЭСБМ wskazują na prawdopodobne łotewskie pochodzenie leksemu w białoruszczyźnie (ЭСБМ, 1978, ss. 163-164). Również W. Smoczyński w Słowniku etymologicznym języka litewskiego pod hasłem sver̃ti odnosi się do łot. svèrt, svēru w znaczeniu 'unosić za pomocą dźwigni, podważać, ważyć' (SEJL, 2007, ss. 618-619). W znaczeniu 'żuraw studzienny' słowo funkcjonuje również w biał. jęz. liter.: асвер (ТСБМ, 1997, ss. 275-276), białoruskich gwarach witebskich: асввер (Касьпяровіч, 2011, s. 26), gwarach północno-zachodniej Białorusi: асвер, асверх, ащвер (ДАБМ, 1963, карта 244; СПЗБ, 1979, s. 106), w tym na Brasławszczyźnie (Brasławszczyzna, 2009, s. 289) oraz gwarach białoruskich Łatgalii (materiały własne autora). Słowo notowane w ПОС (1967, s. 73) z rej. siebieskiego i przylegającego rej. pustoszańskiego: Бывают калоцы высокаи, туда асвер апускают. W zgromadzonych przeze mnie materiałach leksem nie znalazł potwierdzenia.

Bałanda - 'rzadka potrawa, wodnista, mało treściwa zupa', lit. balánda, łot. baloda, balanda 'lebioda; Chenopodium album L.. W pracach J. Laučiūtè (Лаучюте, 1971, s. 79, 1982, s. 38) nazwa ujmowana jest jako bałtyzm w językach słowiańskich. W. Smoczyński (SEJL, 2007, s. 42) również wskazuje na bałtyckie pochodzenie leksemu. W ЭСБМ (1980, s. 32) notowane w znaczeniu przenośnym 'maruda, człowiek leniwy', ze wskazaniem na lit. valandà 'krótki czas' (ЭСБМ, 1980, s. 32). Występuje w gwarach białoruskich północno-zachodniej Białorusi: баланда, балунда (СПЗБ, 1979, ss. 155-156). Leksem zarejestrowany w ПОС (1967, s. 99) z rej. siebieskiego w znaczeniu 'rzadka, mało treściwa zupa': Баланду ещ, полифку 
такую забалтаеш, мукузамешаеш. Zebrane przeze mnie materiały potwierdzają występowanie tej nazwy w rej. siebieskim (w. Bojarinowo): jeść czawo nie była, wajnu pierażyli tieżało, Hospadzi, u wajnu faszysty haniali transzeju kapać, karmili brłandaj kъkaja prpała. [W czasie wojny] bałandu kakuju nawarić, wot, szto jeli [K 1925, Bojarinowo, RU].

Dreb - 'bagno, trzęsawisko', ros. дpeбb, występujące w gwarach pskowskich, archangielskich, twerskich i in. (Лаучюте, 2007, s. 33), por. np. lit. drẽ bti 'bryznąć, rzucić błotem, rzucić czymś mokrym', łot. drêbt 'padać: o mokrym, lepkim śniegu podczas kurniawy' (SEJL, 2007, ss. 120-121), drebêt 'drżeć, trząść się' (Лаучюте, 2007, s. 33). Przez dialektologów słowo dreb zanotowane zostało w rej. siebieskim: Ужэ сафсем пахати ни астаёица, толька лапатям таким, фсё дреп забирае (ПОС, 1994a, s. 201). W materiałach własnych nie mam poświadczenia tego leksemu.

Gịrsa \| dỵrsa - 'stokłosa, chwast z rodziny traw, rosnący przy drogach, w zbożu; Bromus L.', lit. dirsé, lit. dial. girsa, girsè, łot. dzirši. Zarówno J. Karski (Карский, 1962, s. 395), J. Laučiūtė (Лаучюте, 1982, s. 11) jak i W. Smoczyński (SEJL, 2007, s. 115) wskazują na bałtyckie pochodzenie tego leksemu. Również w ЭСБМ (1985, s. 87) określone jako bałtyzm. Występuje na znacznym obszarze pogranicza słowiańsko-bałtyckiego, w gwarach białoruskich północno-zachodniej i północnej Białorusi: zipc, гірса, дзірса, дырса (СПЗБ, 1979, ss. 445, 446; Касьпяровіч, 2011, s. 80; Brasławszczyzna, 2009, ss. 143, 169), w gwarach białoruskich na Litwie i Łotwie: girsa, dyrsa (materiały własne autora) oraz gwarach białoruskich północno-wschodniej Polski: dyrsa (Maryniakowa, Rembiszewska, \& Siatkowski, 2014, s. 130), w polszczyźnie gwarowej na Litwie jako dyrsa (Karaś, 2002, s. 279; SMPPK, b.d.) oraz w gwarach polskich podlasko-suwalskich i północno-wschodniego Mazowsza: dersa (Maryniakowa i in., 2014, s. 130).

Słowo było notowane przez dialektologów w rej. siebieskim i sąsiednim rej. pustoszańskim: А вот үирса, а как па вашыму? Ва ржы расьтеть (ПОС, 1984, s. 163). Wyraz poświadczony w gwarze staroobrzędowców w Polsce, którzy przybyli z południowej Pskowszczyzny (Grek-Pabisowa \& Maryniakowa, 1980). Zebrany przeze mnie materiał potwierdza występowanie tego leksemu w rej. newelskim: Szto dawali za rabotu, pasłuszajtie, trudadzień, a na trudadzień możeć dzwieście hram girsy, a girsa eta adchody żyta [K 1931, Nowochowańsk, RU].

Gudziẹć, pagudzięć - J. Laučiūtė (Лаучюте, 1982, s. 65) rejestruje гудзiน, w w znaczeniu 'ganić, znieważać' i wywodzi od lit. gùdyti, gùdinti 'przyuczać, tworzyć. Również w SEJL (2007, s. 208) występuje jako słowo pochodzenia litewskiego czasownik gùiti 'gnać, pędzić; ganić, potępiać. Autorzy ЭСБМ (1985, s. 111) wskazują z kolei na paralelne występowanie formy w języku litewskim i prasłowiańskim. Leksem funkcjonuje w gwarach północno-zachodniej Białorusi: гудзецъ, гудзіนъь w zna- 
czeniu 'osądzać, obgadywać kogoś; szumieć; burczeć, kłócić się’ (СП3Б, 1979, s. 497), a także w polszczyźnie północnokresowej (Kurzowa, 1993, s. 363).

W ПОС w tym znaczeniu słowo nie było notowane w rejonie siebieskim lub newelskim. W moich materiałach, zebranych w rej. siebieskim, występuje czasownik prefiksalny pagudzieć w znaczeniu 'świętować; hałasować, szumieć: Szto tam swadźba takaja była, paszumieli, pagudzieli i uszli apiać [...] myładyje jeść myładyje, paguliali, papieli, pagudzieli i pajexali, na koni sieli apiać s pieśniami [K 1939, Kazichi, RU]; A my tak bradzili pa kustam da utra, a patom usio hudzieła, usio hrimieła, ciechnika szła kak rieka iszła, a patom zacichła [...] u niemcau była ciechnika, a szto tam hudzieła, nie znaju [K 1924, Newel].

Jownia - 'pomieszczenie do suszenia zboża, lnu, chmielu', lit. jáuja. Zarówno przez J. Karskiego (Карский, 1962, s. 395), J. Laučiūtė (Лаучюте, 1982, s. 12), W. Smoczyńskiego (SEJL, 2007, s. 230), jak i autorów ЭСБM (1985, ss. 188-189) nazwa jest traktowana jako lituanizm. Leksem notowany był już w zabytkach piśmiennictwa białoruskiego XVI w. (Карский, 1962, s. 395; Булыка, 1972, s. 105). Występuje $\mathrm{w}$ podanym znaczeniu w gwarach północno-zachodniej Białorusi: ёўня, еўня (СПЗБ, 1980, s. 127) i w gwarach witebskich: ёўня, еўня (Касьпяровіч, 2011, s. 104). Leksem w postaci jownia zapisano w rej. newelskim: Ёвня, каласники, специальные памешшения - у них снапы сушать, лён мнуть (ПОС, 1994b, s. 104). W zebranych przeze mnie materiałach nazwa nie została potwierdzona.

Kłunia - 'stodoła do przechowywania ziarna, zboża', lit. klúonas i łot. kluōns 'klepisko w stodole'. W słowniku J. Laučiūtè (Лаучюте, 1982, s. 13) i W. Smoczyńskiego (SEJL, 2007, s. 301) notowane jako bałtyzm. Zapożyczenie występowało w zabytkach języka białoruskiego już w wieku XVI (Булыка, 1972, s. 156). Leksem zanotowany w gwarach białoruskich już ponad 100 lat temu przez J. Karskiego (Карский, 1962, s. 396), w gwarach północno-zachodniej Białorusi: клуня (СПЗБ, 1980, ss. 480-481), gwarach witebskich: клуня (Касьпяровіч, 2011, s. 163). Słowo notowane w rej. pustoszańskim położonym pomiędzy Newlem a Siebieżem: У нас клуня не накрыта (ПОС, 2004, s. 229). W zebranym materiale nie mam poświadczenia tego leksemu.

Kowsz - 'naczynie z długą rączką do czerpania wody; długa łyżka do rozlewania płynnych potraw'. Zarówno J. Laučiūtè (Лаучюте, 1982, s. 15), jak i W. Smoczyński (SEJL, 2007, s. 267) wskazują na bałtyckie pochodzenie leksemu: lit. káušas 'naczynie drewniane z trzonkiem, służące do czerpania ziarna, mąki, płynów; chochla do zupy; naczynie do picia', łot. kâuss, kàuss 'czaszka, półkoliste naczynie, chochla, czerpak'. Również autorzy ЭСБМ (1989, ss. 105-106) podkreślają litewskie pochodzenie nazwy. Leksem został potwierdzony w zabytkach piśmiennictwa białoruskiego XVI w. (Булыка, 1972, s. 159). Jego długą tradycję w polszczyźnie, co najmniej od XVI w., poświadcza Zofia Sawaniewska-Mochowa (1990, ss. 179-180). 
Słowo funkcjonuje w gwarach północno-zachodniej Białorusi w znaczeniu 'wielka drewniana łyżka': коўu, коўж (СПЗБ, 1980, ss. 508-509) i gwarach witebskich (Касьпяровіч, 2011, s. 165). Dialektolodzy zanotowali wyraz w rej. newelskim: Ў коўшы муку насыпаеш, з ручечкой, коўшы кала рук хадиу (ПОС, 2004, s. 279). W moich materiałach leksem nie został potwierdzony.

Punnia - 'stodoła', lit. pūné 'plewnik; obora, chlew; okólnik dla bydła; buda, szałas na polu lub łące; nora, pieczara', łot. pūne 'chlew'. Występuje w gwarach łatgalskich, przylegających do Białorusi i rej. siebieskiego (LVDAL, 1999, karte 55). W słownikach J. Laučiūtė (Лаучюте, 1982, s. 20) i W. Smoczyńskiego (SEJL, 2007, ss. 488-489) notowane jako bałtyzm. Słowo jest rozpowszechnione na całym pograniczu bałtycko-słowiańskim, występuje w jęz. wschodniosłowiańskich: biał., ros., ukr.: пуня, w gwarach białoruskich północno-zachodniej i północnej Białorusi, Wileńszczyzny i Łatgalii: пуня (СПЗБ, 1984, ss. 187-189; ДАБМ, 1963, карта 236; Касьпяровіч, 2011, s. 257; Brasławszczyzna, 2009, s. 137; Jankowiak 2009, materiały własne autora), w gwarach północno-wschodniej Polski, polszczyźnie północnokresowej: punia (Kurzowa, 1993, s. 419; SMPPK, b.d.). Leksem zanotowany przeze mnie w rejonie newelskim (Nowochowańsk, Newel): saraj, kak u nas nazywałsia, punia, w etu puniu znaczyć, u adnoj czaści, znaczyć, snapy liżali nimałoczanyje, u druhoj czaści siena [K 1934, Newel, RU]; U nas i chata była, i chlieu i punia i usio da wajny [K 1933, Nowochowańsk, RU].

Przegląd słownictwa współczesnych gwar południowej Pskowszczyzny ukazał, że bałtyzmy stanowią obecnie niewielki odsetek leksyki w mowie miejscowej ludności. W gwarze zanotowano najwięcej słów pochodzenia rosyjskiego i białoruskiego, o wiele mniej jest też polonizmów (które nierzadko trafiły za pośrednictwem białoruskim). Niektórych leksemów nie można też niestety zweryfikować z dwóch powodów Regionalny słownik pskowski (ПОС) obejmuje dotychczas litery od A do P, a materiał własny z badań terenowych zebrany przeze mnie liczy niecałe $20 \mathrm{~h}$ nagrań. Moja baza materiałowa $\mathrm{z}$ terenu Łatgalii (ponad $200 \mathrm{~h}$ nagrań) i Litwy (prawie $100 \mathrm{~h}$ nagrań) oraz dokumentacja zgromadzona przez innych dialektologów $\mathrm{z}$ obszaru północnej Białorusi wskazują, że trzeba dysponować możliwie bogatym i różnorodnym zasobem materiału, by móc wyekscerpować z niego obszerniejszy zestaw bałtyzmów. Zagadnienie żywotności leksyki bałtyckiej na terytorium Pskowszczyzny wymaga szerzej zakrojonych badań terenowych.

Z wcześniejszych eksploracji przeprowadzonych przez litewską badaczkę J. Laučiūtè wynika, że poza wyżej wymienionymi bałtyzmami używane były jeszcze w latach 70 . XX w. na interesującym mnie obszarze takie nazwy, jak: ащакu 'łuski z ziaren zbóż' (rej. siebieski), гигялй 'skrzyp polny' (rej. siebieski), дирваин 'ugór, ziemia leżąca odłogiem' (rej. siebieski), клумба 'obuwie ze skórzanym wierzchem na drewnianej podeszwie' (rej. siebieski), курмелль zool. 'kiełb, miętus pospolity' (rej. siebieski), 
кятұрка 'klin w spodniach damskich; rozporek' (rej. siebieski), луnammıци 'człowiek z dużymi ustami' (rej. siebieski), (об)жергнуть 'przekroczyć, przestąpić' (rej. siebieski), otŏs \| atŏs 'sznur albo pręt łączący oś przednią wozu z hołoblą' (rej. newelski), napcyא 'prosię' (rej. newelski, siebieski), nympa 'polewka na mące; kasza; pożywienie dla źrebaka' (rej. newelski), рявгеннья 'zakwaszona kasza słodowa' (rej. siebieski), свирна 'spichlerz do przechowywania ziarna; także pomieszczenie do składania snopów, siana' (rej. siebieski), склют 'narzędzie stolarskie, topór' (rej. siebieski), шащo $\kappa$ zool. 'tchórz' (rej. siebieski), шула 'narożna pionowa belka budynku' (rej. newelski) (Лаучюте, 1971, ss. 79-85).

Wszystkie notowane przeze mnie słowa reprezentują dawne zapożyczenia, funkcjonujące w gwarach białoruskich i pogranicza białorusko-rosyjskiego już od kilkuset lat. Zostały one zaadaptowane, zarówno fonetycznie, jak i gramatycznie, i są traktowane przez miejscową ludność jako wyrazy własne, białoruskie / rosyjskie. Występowanie niektórych leksemów, przede wszystkim na południu badanego przeze mnie terytorium, może wskazywać na to, że zachowaniu bałtyzmów sprzyjała gwara białoruska. Tam, gdzie mowa rozmówcy nasycona jest większą liczbą białorutenizmów, również i bałtyzmy leksykalne występują częściej. Zarówno po stronie łotewskiej, jak i białoruskiej, gdzie gwary mają więcej zachowanych cech białoruskich, liczba bałtyzmów jest zdecydowanie wyższa. Niewątpliwie większość bałtyzmów przedostała się do mowy mieszkańców rejonu siebieskiego i newelskiego w związku z kontaktami terytorialnymi, tj. bliskim położeniem geograficznym Pskowszczyzny z państwami bałtyckimi, przede wszystkim Łotwą. Miejscowa ludność kontaktowała się w przeszłości nie tylko z Bałtami, ale również z innymi Białorusinami zamieszkującymi ziemie położone bardziej na południe (w obecnych granicach Białorusi), a także z Polakami, którzy są obecni na tym terenie od czasów unii lubelskiej w 1569 r.

Można szacować, że powszechniejsze występowanie bałtyzmów na Pskowszczyźnie związane było z uwarunkowaniami historycznymi - czasami WKL i Rzeczypospolitej (kiedy zarówno Siebież, jak i Newel wchodziły w jej skład) i funkcjonowania guberni witebskiej. Obecnie większość moich rozmówców używa ekwiwalentów rosyjskich, co wskazuje na to, że wraz z rusyfikacją dawnej gwary białoruskiej zmniejsza się systematycznie liczba bałtyzmów.

\section{Spis informatorów}

[K 1941, Zasitino, RU] - kobieta ur. w 1941 r. w Zasitino (kilka kilometrów od łotewskiej granicy), rejon siebieski, ukończyła 7 klas szkoły rosyjskiej, całe życie przepracowała w kołchozie, uważa się za Rosjankę. Jej mowę należy określić jako gwarę mieszaną białorusko-rosyjską z przewagą cech rosyjskich. Wywiad z 26.06.2014 r. 
[K 1939, Kazichi, RU] - kobieta ur. we wsi Rżawki Litewskie, kilka kilometrów od wsi Kazichi, rejon siebieski, ukończyła 3 klasy szkoły rosyjskiej, prawosławna, uważa się za Rosjankę. Jej mowę należy określić jako gwarę mieszaną białorusko-rosyjską z przewagą cech rosyjskich. Wywiad z 27.06.2014 r.

[K 1925, Bojarinowo, RU] - kobieta ur. w 1925 r. we wsi Zamosznia koło Bojarinowa, prawosławna, uważa się za Rosjankę. Ukończyła 2 klasy szkoły rosyjskiej. Jej gwarę należy określić jako mieszaną białorusko-rosyjską z dużą ilością cech białoruskich. Wywiad z 28.06.2014 r.

[K 1931, Nowochowańsk, RU] - kobieta, ur. w 1931 r. we wsi Jermoszyna, turyczyński sielsowiet, rejon newelski, od lat 50. XX w. mieszka w Nowochowańsku, ukończyła 4 klasy szkoły rosyjskiej, prawosławna. Całe swoje życie przepracowała w kołchozie. Uważa, że ona i jej sąsiedzi mówią po rosyjsku. Jej mowę należy określić jako gwarę mieszaną białorusko-rosyjską z dużą ilością cech białoruskich. Wywiad z 04.07.2014 r.

[K 1935, Nowochowańsk, RU] - kobieta, ur. w 1935 r. we wsi Rudaki (nowochowański sielsowiet) newelskiego rejonu, potem przeniosła się do wsi Szulgi (również nowochowański sielsowiet), ukończyła 7 klas szkoły rosyjskiej, prawosławna. Całe życie przepracowała w kołchozie. Swój język określa jako rosyjski. Jej mowę należy określić jako gwarę mieszaną białorusko-rosyjską, z dużą ilością cech białoruskich. Wywiad z 04.07.2014 r.

[K 1934, Newel] - kobieta, ur. w 1934 r. we wsi Barok, dubinienski sielsowiet, rejon newelski, obecnie mieszka w Newlu, ukończyła 7 klas szkoły rosyjskiej, prawosławna. Pracowała w zakładzie obróbki lnu. Uważa, że rozmawia w języku „zmieszanym”. Uważa się za Rosjankę. Jej gwarę należy określić jako mieszaną białorusko-rosyjską z dużą ilością cech białoruskich. Wywiad z 03.07.2014 r.

[K 1928, Posiń, LV] - kobieta ur. w 1928 r. we wsi Gorbacze koło Posinia, wschodnia Łotwa, kilka kilometrów od granicy z Rosją. Ukończyła 4 klasy (2 klasy szkoły polskiej i 2 białoruskiej), katoliczka, uważa się za Polkę. Całe życie przepracowała w kołchozie. Jej mowę należy określić jako gwarę mieszaną białorusko-rosyjską z przewagą cech białoruskich. Wywiad z 16.08.2014 r.

[K 1924, Iwancewo] - kobieta, ur. w 1924 r. w Iwancewie rejonu newelskiego i tutaj spędziła całe życie. Prawosławna, ukończyła 7 klas szkoły rosyjskiej. Uważa się za Rosjankę. Pracowała w kołchozie. Jej mowę można określić jako mieszaną białorusko-rosyjską gwarę $\mathrm{z}$ przewagą cech rosyjskich. Wywiad z 02.07.2014 r.

[K 1915, Kanaszowo/ Czerniecewo] - kobieta, ur. w 1915 r. we wsi Zabłudowje (10 km na południe od Iwancewa), rejon newelski. W 1929 r. przeniosła się do Kanaszowa (ob. Czerniecewo). Całe życie przepracowała w kołchozie. Uważa się za Rosjankę, jej język można określić jako gwarę mieszaną białorusko-rosyjską z licznymi cechami białoruskimi. Wywiad z 02.07.2014 r.

[K 1925, Opuchliki] - kobieta, ur. w 1925 r. w Newlu. W dzieciństwie przeprowadziła się z rodzicami do Turyczyna. Mieszka w Opuchlikach od 1950 r., ukończyła 8 klas szkoły rosyjskiej, prawosławna. Uważa się za Rosjankę, a swój język nazwała rosyjskim. Jej mowę należy uznać za język rosyjski z białoruskimi elementami. Wywiad z 03.07.2014 r.

[K 1932, Spas-Bałazdyń] - kobieta, ur. w 1932 r. we wsi Nowinki, rejon newelski, uczęszczała do szkoły rosyjskiej, prawosławna. Pracowała w kołchozie. Uważa się za Rosjankę. Według niej i ona, i wszyscy dookoła rozmawiają po rosyjsku. Jej mowę należy określić jako język rosyjski z cechami białoruskimi. Wywiad z 03.07.2014 r. 
[K 1928, Ust'-Dołysy] - kobieta, ur. w 1928 r. we wsi Łukianowo (rejon pustoszański), od 1967 r. mieszka w Ust'-Dołysy. Ukończyła 2 klasy szkoły rosyjskiej. Całe życie przepracowała w kołchozie, prawosławna. Uważa się za Rosjankę. Swoją mowę określiła jako rosyjską. Jej język można określić jako mieszaną białorusko-rosyjską gwarę z licznymi cechami białoruskimi. Wywiad z 02.07.2014 r.

\section{Skróty}

Brasławszczyzna - Smułkowa, E. (Red.). (2009). Brasławszczyzna. Pamięć i współczesność (T. 2: Słownictwo dwujęzycznych mieszkańców rejonu: Słownik brasławski). Warszawa: Wydawnictwa Uniwersytetu Warszawskiego.

LVDAL - - Bušmane, B., Laumane, B., \& Stafecka, A. (1999). Latviešu valodas dialektu atlants: Leksika. Rīga: Zinātne.

SEJL - Smoczyński, W. (2007), Słownik etymologiczny języka litewskiego / Lietuviu kalbos etimologinis žodynas. Vilnius: Vilniaus universiteto leidykla.

SMPPK - Grek-Pabisowa, I.(Red.), Słownikmówionejpolszczyzny pólnocnokresowej. Autorzy haseł: B. Biesiadowska-Magdziarz, M. Jankowiak, M. Ostrówka [maszynopis].

ДАБМ - Аванесаў, P. I. (Red.). (1963). Дьялекталагічны атлас беларускай мовы. Мінск: Інстытут мовазнаўства імя Якуба Коласа Акадэміі навук Беларускай ССР.

ПОС - Псковский областной словарь с историческими данными. (1967-). (Т. 1-). Ленинград / Ст. Петербург: Издательство Ленинградского университета / Санктпетербургский государственный университет.

СПЗБ - Мацкевіч, Ю. Ф. (Red.). (1979-1986). Слоўнік беларускіх гаворак паўночна-заходняй Беларусі і яе пагранічча у пяці томах (Т. 1- 5). Мінск: Навука і тэхніка.

ТБСМ - - Суднік, М. П., \& Крыўко, M.H. (Red.). (2002). Тлумачальны слоўнік беларускай літаратурнай мовы. Мінск: Беларуская энцыклапедыя.

ЭСБМ - Мартынаў, В. У., \& Цыхун, Г. А. (Red.). (1978-2010). Этыммалагічны слоўнік беларускай мовы. (Т. 1-13). Мінск: Навука і тэхніка.

\section{Bibliografia}

Bednarczuk, L. (2010). Językowy obraz Wielkiego Księstwa Litewskiego: Millennium Lithuaniae MIX-MMIX. Kraków: Lexis.

Bušmane, B., Laumane, B., \& Stafecka, A. (1999). Latviešu valodas dialektu atlants: Leksika [LVDAL]. Rìga: Zinātne.

Grek-Pabisowa, I. (1986). Polonizmy w gwarach pskowskich. W J. Majowa (Red.), Język i jego odmiany w aspekcie porównawczym (ss. 183-194). Wrocław: Zakład Narodowy im. Ossolińskich (Prace Slawistyczne, 53). 
Grek-Pabisowa, I., \& Maryniakowa, I. (1980). Słownik gwary starowierców mieszkających $w$ Polsce. Wrocław: Zakład Narodowy im. Ossolińskich.

Grek-Pabisowa, I., Biesiadowska-Magdziarz, B., Jankowiak, M., \& Ostrówka, M. (b.d.). Słownik mówionej polszczyzny pótnocnokresowej [SMPPK]. Maszynopis.

Jankowiak, M. (2009). Gwary białoruskie na Łotwie w rejonie krasławskim: Studium socjolingwistyczne. Warszawa: Slawistyczny Ośrodek Wydawniczy.

Jankowiak, M. (2015). Współczesne gwary białoruskie na południowej Pskowszczyźnie: Rejon newelski. Slavia, 84(2), 213-231.

Karaś, H. (2002). Gwary polskie na Kowieńszczyźnie. Warszawa: Wydawnictwo „Aušra”.

Kurzowa, Z. (1993). Język polski Wileńszczyzny i kresów pótnocno-wschodnich XVI-XX w. Warszawa: Wydawnictwo Naukowe PWN.

Maryniakowa, I., Rembiszewska, D. K., \& Siatkowski, J. (2014). Różnojęzyczne słownictwo gwarowe Podlasia, Suwalszczyzny i pótnocno-wschodniego Mazowsza. Warszawa: Slawistyczny Ośrodek Wydawniczy.

Rutkowska, K. (2014). O warstwach leksyki pochodzenia litewskiego na obszarze ignalińsko-jezioroskim. Acta Baltico-Slavica, 38, 126-152. http://dx.doi.org/10.11649/abs.2014.003

Rutkowska, K. (2015). Lituanizmy w gwarach polskich pogranicza litewsko-łotewsko-białoruskiego. W B. Falińska \& H. Karaś (Red.), Studia Gwaroznawcze (T. 2: Z zagadnień leksyki i słowotwórstwa, ss. 155-168). Łomża: Łomżyńskie Towarzystwo Naukowe im. Wagów.

Sawaniewska-Mochowa, Z. (1990). Poradnik Jana Karłowicza jako źródło poznania potocznej polszczyzny pótnocnokresowej: Słownictwo. Warszawa: Wydawnictwa Uniwersytetu Warszawskiego. (Polono-Slavica Varsoviensia, 5).

Smoczyński, W. (2007). Słownik etymologiczny języka litewskiego [SEJL]. Wilno: Wydawnictwo Uniwersytetu Wileńskiego.

Smułkowa, E. (2002). Pojęcie gwar przejściowych i mieszanych na polsko-białorusko-ukraińskim pograniczu językowym. W E. Smułkowa, Białoruś i pogranicza: Studia o języku i społeczeństwie (ss. 336-348). Warszawa: Wydawnictwa Uniwersytetu Warszawskiego.

Smułkowa E. (Red.). (2009). Brasławszczyzna: Pamięć i współczesność (T. 2: Słownictwo dwujęzycznych mieszkańców rejonu: Słownik brasławski) [Brasławszczyzna]. Warszawa: Wydawnictwa Uniwersytetu Warszawskiego.

Tichomirow, A. (2005). Struktura wyznaniowa i etniczna guberni witebskiej w pierwszej połowie lat 60. XIX wieku. W E. Skrobocki (Red.), Problemy świadomości narodowej ludności polskiej na Białorusi: Materiały III międzynarodowej konferencji naukowej. (Grodno, 22-24 listopada 2004) (ss. 165-182). Grodno: Związek Polaków na Białorusi. Pobrano 12 września 2016, z http://pawet.net/library/history/bel_history/tich/26/

Turska, H. (1982). O powstaniu polskich obszarów językowych na Wileńszczyźnie. W J. Rieger \& W. Werenicz (Red.), Studia nad polszczyzną kresowa (T. 1, ss. 19-121). Wrocław: Zakład Narodowy im. Ossolińskich, Wydawnictwo Polskiej Akademii Nauk. (Prace Jezzykoznawcze, 98).

Zinkevičius, Z. (1998). The history of the Lithuanian language. Vilnius: Mokslo ir enciklopediju leidybos institutas. 
Mirosław Jankowiak Leksyka pochodzenia bałtyckiego w mieszanych białorusko-rosyjskich gwarach...

Аванесов, Р. И. (1949). Очерки русской диалектологии. Москва: Государственное учебнопедагогическое издательство Министерства просвещения РСФСР.

Аванесаў, P. I. (Red.). (1963). Дьялекталагічны атлас беларускай мовы [ДАБМ]. Мінск: Інстытут мовазнаўства імя Якуба Коласа Акадэміі навук Беларускай ССР.

Бузук, П. (1926). Да характарыстыкі паўночна-беларускіх дыялектаў: Гутаркі невельскага і вяліскага паветаў. Менск: Інстытут Беларускае Культуры.

Булыка, А. М. (1972). Даўнія запазычанні беларускай мовы. Мінск: Выдавецтва «Навука і тэхніка».

Булыка, А. М. (2015). Литуанизмы старобелорусского литературно-письменного языка в отношении к белорусским диалектом. W A. М. Булыка, Выбраныя працы (ss. 165-174). Мінск: Беларуская навука.

Ванагас, А. П. (1983). Проблема древнейших балто-славянских языковых отночений в свете балтийских гидронимических лексем. Вильнюс: Академия наук Литовской ССР.

Данные Всероссийской переписи населения 2002 года: Таблица 02c, 34r-Pskov. (2004). Москва.

Дурново, Н. Н., Соколов, Н. Н, \& Ушаков, Д. Н. (1915). Опьт діалектологической карты русскаго языка въ Европь съ приложеніем очерка русской діалектологіи. Москва.

Захарова, К. Ф., \& Орлова, В. Г. (1970). Диалектное членение русского языка. Москва: Просвещение.

Карский, Е.Ф. (1903). Энтографическая карта бьлорусскаго племени. Варшава.

Карский, Е. Ф. (1962). К вопросу о влиянии литовского и латышского языков на белорусское наречье. W Е. Ф. Карский, Труды по белорусскому и другим славянским языкам (ss. 384-398). Москва: Издательство Академии Наук СССР.

Касаткин, Л. Л. (Red.). (2005). Русская диалектология. Москва: Издательский центр «Академия».

Касьпяровіч, М. (2011). Віцебскі краёвы слоўнік: Матар’яль. Менск: Arche.

Колесов, В. В. (Red.). (2006). Русская диалектология. Москва: Дрофа.

Лаумане, Б. (1974). Латышско-русско-белорусско-польские лексические контакты по материалам Диалектологического атласа латышского языка. W T. M. Судник (Red.), Балто-славянские исследования (ss. 183-205). Москва: Издательство «Наука».

Лаучюте, Ю. А. (1971). Лексические балтизмы в псковских говорах. Kalbotyra, 12(2), 77-91.

Лаучюте, Ю. А. (1982). Словарь балтизмов в славянских языках. Ленинград: Наука.

Лаучюте, Ю. А. (2007). Субстратные балтизмы в диалектной лексике русского языка. W Latvijas Universitātes raksti. 720. Sējums. Valodniecība: Studia ethymologica germanobalto-slavica (ss. 31-36.). Rìga: Latvijas Universitāte.

Мартынаў, В. У., \& Цыхун, Г. А. (Red.). (1978-2010). Этыммалагічны слоўнік беларускай мовы [ЭСБМ] (Т. 1-13). Мінск: Навука і тэхніка.

Мартынаў, В. У., \& Цыхун, Г. А. (Red.). (1978). Этымалагічны слоўнік беларускай мовы [ЭСБМ] (Т. 1). Мінск: Навука і тэхніка.

Мартынаў, В. У., \& Цыхун, Г. А. (Red.). (1980). Этыммалагічны слоўнік беларускай мовы [ЭСБМ] (Т. 2). Мінск: Навука і тэхніка.

Мартынаў, В. У., \& Цыхун, Г. А. (Red.). (1985). Этымалагічны слоўнік беларускай мовы [ЭСБМ] (Т. 3). Мінск: Навука і тэхніка. 
Мартынаў, В. У., \& Цыхун, Г. А. (Red.). (1989). Этымалагічны слоўнік беларускай мовы [ЭСБМ] (Т. 5). Мінск: Навука і тэхніка.

Мацкевіч, Ю. Ф. (Red.). (1979-1986). Слоўнік беларускіх гаворак паўночна-заходняй Беларусі i яе пагранічча ў пяці томах [СПЗБ] (Т. 1-5). Мінск: Навука і тэхніка.

Мацкевіч, Ю.Ф. (Red.). (1979). Слоўнік беларускіх гаворак паўночна-заходняй Беларусі i яе пагранічча ў пящі томах [СПЗБ] (Т. 1). Мінск: Навука і тэхніка.

Мацкевіч, Ю.Ф. (Red.). (1980). Слоўнік беларускіх гаворак паўночна-заходняй Беларусі i яе пагранічча ў пяці томах [СПЗБ] (Т. 2). Мінск: Навука і тэхніка.

Мацкевіч, Ю. Ф. (Red.). (1984). Слоўнік беларускіх гаворак паўночна-заходняй Беларусі i яе пагранічча ў пяці томах [СПЗБ] (Т. 4). Мінск: Навука і тэхніка.

Псковский областной словарь с историческими данными [ПОС]. (1967-) (Т. 1-). Ленинград / Ст. Петербург: Издательство Ленинградского университета / Санктпетербургский государственный университет.

Псковский областной словарь с историческими данными [ПОС]. (1967) (Т. 1). Ленинград: Издательство Ленинградского университета.

Псковский областной словарь с историческими данными [ПОС]. (1984) (Т. 6). Ленинград: Издательство Ленинградского университета.

Псковский областной словарь с историческими данными [ПОС]. (1994а) (Т. 9). Ст. Петербург: Санктпетербургский государственный университет.

Псковский областной словарь с историческими данными [ПОС]. (1994b) (Т. 10). Ст. Петербург: Санктпетербургский государственный университет.

Псковский областной словарь с историческими данными [ПОС]. (2004) (Т. 14). Ст. Петербург: Санктпетербургский государственный университет.

Риттих, А. Ф. (1875). Этнографическая карта европейской России. С. Петербург.

Суднік, М. П., \& Крыўко, М. Н. (Red.). (2002). Тлумачальны слоўнік беларускай літаратурнай мовы [ТБСМ]. Мінск: Беларуская энцыклапедыя.

\section{Bibliography (Transliteration)}

Avanesaŭ, R. I. (Ed.). (1963). Dyialektalahichny atlas belaruskaĭ movy [DABM]. Minsk: Instytut movaznaŭstva imia IAkuba Kolasa Akadėmii navuk Belaruskă SSR.

Avanesov, R. I. (1949). Ocherki russkoĭ dialektologii. Moskva: Gosudarstvennoe uchebnopedagogicheskoe izdatel'stvo Ministerstva prosveshcheniia RSFSR.

Bednarczuk, L. (2010). Językowy obraz Wielkiego Księstwa Litewskiego: Millennium Lithuaniae MIX-MMIX. Kraków: Lexis.

Bulyka, A. M. (1972). Daŭniia zapazychanni belaruskaŭ movy. Minsk: Vydavetstva «Navuka i tèkhnika».

Bulyka, A. M. (2015). Lituanizmy starobelorusskogo literaturno-pis'mennogo iazyka v otnoshenii k belorusskim dialektom. In A. M. Bulyka, Vybranyia pratsy (pp. 165-174). Minsk: Belaruskaia navuka. 
Bušmane, B., Laumane, B., \& Stafecka, A. (1999). Latviešu valodas dialektu atlants: Leksika [LVDAL]. Rìga: Zinātne.

Buzuk, P. (1926). Da kharaktarystyki paŭnochna-belaruskikh dyialektaŭ: Hutarki nevel'skaha i vialiskaha pavetaŭ. Mensk: Instytut Belaruskae Kul'tury.

Dannye Vserossiǔskoĭ perepisi naseleniia 2002 goda: Tablitsa 02c, 34r-Pskov. (2004). Moskva.

Durnovo, N. N., Sokolov, N. N, \& Ushakov, D. N. (1915). Opyt dīalektologicheskoŭ karty russkago iazyka v Evropie s prilozhenīem ocherka russkoŭ dīalektologīi. Moskva.

Grek-Pabisowa, I. (1986). Polonizmy w gwarach pskowskich. In J. Majowa (Ed.), Język i jego odmiany w aspekcie porównawczym (pp. 183-194). Wrocław: Zakład Narodowy im. Ossolińskich. (Prace Slawistyczne, 53)

Grek-Pabisowa, I., \& Maryniakowa, I. (1980). Słownik gwary starowierców mieszkajacych $w$ Polsce. Wrocław: Zakład Narodowy im. Ossolińskich.

Grek-Pabisowa, I., Biesiadowska-Magdziarz, B., Jankowiak, M., \& Ostrówka, M. (n.d.). Słownik mówionej polszczyzny pótnocnokresowej [SMPPK]. Typescript.

Jankowiak, M. (2009). Gwary białoruskie na Łotwie w rejonie krasławskim: Studium socjolingwistyczne. Warszawa: Slawistyczny Ośrodek Wydawniczy.

Jankowiak, M. (2015). Współczesne gwary białoruskie na południowej Pskowszczyźnie: Rejon newelski. Slavia, 84(2), 213-231.

Karaś, H. (2002). Gwary polskie na Kowieńszczyźnie. Warszawa: Wydawnictwo „Aušra”.

Karskiü, E. F. (1903). Ėtnograficheskaia karta bielorusskago plemeni. Varshava.

Karskiĭ, E. F. (1962). K voprosu o vliianii litovskogo i latyshskogo iazykov na belorusskoe narech'e. In E. F. Karskiı̌, Trudy po belorusskomu i drugim slavianskim iazykam (pp. 384-398). Moskva: Izdatel'stvo Akademii Nauk SSSR.

Kas'piarovich, M. (2011). Vitsebski kraëvy sloŭnik: Matar'ialy. Mensk: Arche.

Kasatkin, L. L. (Ed.). (2005). Russkaia dialektologiia. Moskva: Izdatel'skiĭ tsentr «Akademiia».

Kolesov, V. V. (Ed.). (2006). Russkaia dialektologiia. Moskva: Drofa.

Kurzowa, Z. (1993). Język polski Wileńszczyzny i kresów północno-wschodnich XVI-XX w. Warszawa: Wydawnictwo Naukowe PWN.

Lauchiute, I. A. (1971). Leksicheskie baltizmy v pskovskikh govorakh. Kalbotyra, 12(2), 77-91.

Lauchiute, I. A. (1982). Slovar' baltizmov v slavianskikh iazykakh. Leningrad: Nauka.

Lauchiute, I. A. (2007). Substratnye baltizmy v dialektnoŭ leksike russkogo iazyka. In Latvijas Universitātes raksti. 720. Sējums. Valodniecība: Studia ethymologica germano-balto-slavica (pp. 31-36.). Rìga: Latvijas Universitāte.

Laumane, B. (1974). Latyshsko-russko-belorusko-pol'skie leksicheskie kontakty po materialam Dialektologicheskogo atlasa latyshskogo iazyka. In T. M. Sudnik (Ed.), Balto-slavianskie issledovaniia (pp. 183-205). Moskva: Izdatel'stvo «Nauka».

Martynaŭ, V. U., \& Tsykhun, H. A. (Eds.). (1978). Etymalahichny sloŭnik belaruskaŭ movy [ĖSBM] (Vol. 1). Minsk: Navuka i tèkhnika.

Martynaŭ, V. U., \& Tsykhun, H. A. (Eds.). (1978-2010). Ėtymalahichny sloŭnik belaruskaĭ movy [ÉSBM] (Vols. 1-13). Minsk: Navuka i tèkhnika. 
Martynaŭ, V. U., \& Tsykhun, H. A. (Eds.). (1980). Etymalahichny sloŭnik belaruskaĭ movy [ËSBM] (Vol. 2). Minsk: Navuka i tèkhnika.

Martynaŭ, V. U., \& Tsykhun, H. A. (Eds.). (1985). Etymalahichny sloŭnik belaruskaŭ movy [ËSBM] (Vol. 3). Minsk: Navuka i tèkhnika.

Martynaŭ, V. U., \& Tsykhun, H. A. (Eds.). (1989). Étymalahichny sloŭnik belaruskă movy [ËSBM] (Vol. 5). Minsk: Navuka i tėkhnika.

Maryniakowa, I., Rembiszewska, D. K., \& Siatkowski, J. (2014). Różnojęzyczne słownictwo gwarowe Podlasia, Suwalszczyzny i północno-wschodniego Mazowsza. Warszawa: Slawistyczny Ośrodek Wydawniczy.

Matskevich, I. F. (Ed.). (1979). Sloŭnik belaruskikh havorak paŭnochna-zakhodniaĭ Belarusi i iae pahranichcha ŭ piatsi tomakh [SPZB] (Vol. 1). Minsk: Navuka i tėkhnika.

Matskevich, I. F. (Ed.). (1979-1986). Sloŭnik belaruskikh havorak paŭnochna-zakhodniaı̆ Belarusi i iae pahranichcha ŭ piatsi tomakh [SPZB] (Vols. 1-5). Minsk: Navuka i tèkhnika.

Matskevich, I. F. (Ed.). (1980). Sloŭnik belaruskikh havorak paŭnochna-zakhodniaŭ Belarusi i iae pahranichcha ŭ piatsi tomakh [SPZB] (Vol. 2). Minsk: Navuka i tèkhnika.

Matskevich, I. F. (Ed.). (1984). Sloŭnik belaruskikh havorak paŭnochna-zakhodniaı̆ Belarusi i iae pahranichcha ŭ piatsi tomakh [SPZB] (Vol. 4). Minsk: Navuka i tèkhnika.

Pskovskiŭ oblastnoŭ slovar's istoricheskimi dannymi [POS]. (1967-) (Vols. 1-). Leningrad / St. Peterburg: Izdatel'stvo Leningradskogo universiteta / Sanktpeterburgskil gosudarstvenny̌̆ universitet.

Pskovskiŭ oblastno ̌ slovar's istoricheskimi dannymi [POS]. (1967) (Vol. 1). Leningrad: Izdatel'stvo Leningradskogo universiteta.

Pskovskiŭ oblastno ̌ slovar's istoricheskimi dannymi [POS]. (1984) (Vol. 6). Leningrad: Izdatel'stvo Leningradskogo universiteta.

Pskovskiŭ oblastnoĭ slovar's istoricheskimi dannymi [POS]. (1994a) (Vol. 9). St. Peterburg: Sanktpeterburgskiı̆ gosudarstvennyı̆ universitet.

Pskovskiŭ oblastnoŭ slovar' s istoricheskimi dannymi [POS]. (1994b) (Vol. 10). St. Peterburg: Sanktpeterburgskiı̌ gosudarstvennyı̆ universitet.

Pskovskil̆ oblastnoĭ slovar's istoricheskimi dannymi [POS]. (2004) (Vol. 14). St. Peterburg: Sanktpeterburgskiı̆ gosudarstvennyı̆ universitet.

Rittikh, A. F. (1875). Ėtnograficheskaia karta evropeřskŏ Rossii. S. Peterburg.

Rutkowska, K. (2014). O warstwach leksyki pochodzenia litewskiego na obszarze ignalińskojezioroskim. Acta Baltico-Slavica, 38, 126-152. http://dx.doi.org/10.11649/abs.2014.003

Rutkowska, K. (2015). Lituanizmy w gwarach polskich pogranicza litewsko-łotewskobiałoruskiego. In B. Falińska \& H. Karaś (Eds.), Studia Gwaroznawcze (Vol. 2: Z zagadnień leksyki i słowotwórstwa, pp. 155-168). Łomża: Łomżyńskie Towarzystwo Naukowe im. Wagów.

Sawaniewska-Mochowa, Z. (1990). Poradnik Jana Karłowicza jako źródło poznania potocznej polszczyzny północnokresowej: Słownictwo. Warszawa: Wydawnictwa Uniwersytetu Warszawskiego. (Polono-Slavica Varsoviensia, 5).

Smoczyński, W. (2007). Słownik etymologiczny języka litewskiego [SEJL]. Wilno: Wydawnictwo Uniwersytetu Wileńskiego. 
Smułkowa E. (Ed.). (2009). Brasławszczyzna: Pamięć i współczesność (Vol. 2: Słownictwo dwujęzycznych mieszkańców rejonu (Słownik brasławski)) [Brasławszczyzna]. Warszawa: Wydawnictwa Uniwersytetu Warszawskiego.

Smułkowa, E. (2002). Pojęcie gwar przejściowych i mieszanych na polsko-białoruskoukraińskim pograniczu językowym. In E. Smułkowa, Białoruś i pogranicza: Studia o języku i społeczeństwie (pp. 336-348). Warszawa: Wydawnictwa Uniwersytetu Warszawskiego.

Sudnik, M.P., \& Kryŭko, M. N. (Eds.). (2002). Tlumachal'ny sloŭnik belaruskaĭ litaraturnă movy [TBSM]. Minsk: Belaruskaia ėntsyklapedyia.

Tichomirow, A. (2005). Struktura wyznaniowa i etniczna guberni witebskiej w pierwszej połowie lat 60. XIX wieku. In E. Skrobocki (Ed.), Problemy świadomości narodowej ludności polskiej na Białorusi: Materiały III międzynarodowej konferencji naukowej. (Grodno, 22-24 listopada 2004) (pp. 165-182). Grodno: Związek Polaków na Białorusi. Retrieved 12 September 2016, from http://pawet.net/library/history/bel_history/tich/26/

Turska, H. (1982). O powstaniu polskich obszarów językowych na Wileńszczyźnie. In J. Rieger \& W. Werenicz (Eds.), Studia nad polszczyzna kresowa (Vol. 1, pp. 19-121). Wrocław: Zakład Narodowy im. Ossolińskich, Wydawnictwo Polskiej Akademii Nauk. (Prace Językoznawcze, 98).

Vanagas, A. P. (1983). Problema drevneı̌shikh balto-slavianskikh iazykovykh otnosheniǔ v svete baltiǔskikh gidronimicheskikh leksem. Vil'nius: Akademiia nauk Litovskor SSR.

Zakharova, K. F., \& Orlova, V. G. (1970). Dialektnoe chlenenie russkogo iazyka. Moskva: Prosveshchenie.

Zinkevičius, Z. (1998). The history of the Lithuanian language. Vilnius: Mokslo ir enciklopediju leidybos institutas.

\section{Leksyka pochodzenia bałtyckiego w mieszanych białorusko-rosyjskich gwarach południowej Pskowszczyzny (rejon Siebieża i Newla)}

\section{Streszczenie}

W przedstawionym artykule została omówiona leksyka bałtyckiego pochodzenia, funkcjonująca we współczesnych gwarach mieszanych białorusko-rosyjskich. Przeanalizowano słownictwo gwar funkcjonujących w południowej części obwodu pskowskiego - w rejonie Siebieża i Newla, które wchodziły niegdyś w skład Wielkiego Księstwa Litewskiego i Rzeczypospolitej. Za podstawę materiałową posłużyły nagrania własne autora, zebrane w trakcie ekspedycji dialektologicznej przeprowadzonej w ramach projektu TriMCO (Triangulation Approach for Modelling Convergence with a High Zoom-In Factor) w 2014 r. oraz wydane dotychczas tomy Regionalnego słownika pskowskiego (Псковский областной словарь - ПОС). 
Południowa część obwodu pskowskiego od setek lat jest obszarem stykania się różnych języków i dialektów (rosyjski, białoruski, litewski, łotewski, polski, jidysz). Słownictwo bałtyckie odnosi się w większości do najstarszej warstwy leksyki i dotyczy m.in. tradycyjnej uprawy roli, gospodarstwa, otaczającej przyrody czy cech charakteru i wyglądu człowieka. Zebrany materiał ukazał, że zachowaniu bałtyzmów sprzyjało funkcjonowanie na badanym obszarze gwary białoruskiej (obecnie mieszanej białorusko-rosyjskiej). Tam, gdzie mowa mieszkańców wsi ma charakter rosyjski, a cech białoruskich zachowało się niewiele, liczba bałtyzmów również jest znikoma, a rozmówcy nierzadko podkreślają, że dane słowo znają tylko z dzieciństwa i nikt już tak nie nazywa konkretnych przedmiotów.

Słowa kluczowe: bałtyzmy; mieszane gwary białorusko-rosyjskie; zapożyczenia; obwód pskowski

\title{
The vocabulary of Baltic origin in mixed Belarusian-Russian dialects of the south Pskov region (the area of Sebezh and Nevel)
}

\begin{abstract}
The article discusses the issue of the vocabulary of Baltic origin which functions in contemporary mixed Belarusian-Russian dialects. It contains analysis of the vocabulary of dialects functioning in the southern part of Pskov region - in the area of Sebezh and Nevel which once were part of the Polish-Lithuanian Commonwealth. The material basis was the author's own recordings collected during a dialectological expedition carried out as a part of the TriMCo (Triangulation Approach for Modelling Convergence with a High Zoom-In Factor) project in 2014 as well as volumes of the Pskov regional dictionary (Псковский областной словарь).

The southern part of Pskov region has been the place of contact of various languages and dialects (Russian, Belarusian, Lithuanian, Latvian, Polish, Yiddish). The Baltic vocabulary is connected mainly with the oldest layer of the lexis and concerns the traditional agriculture, farming, nature or features of people's character and appearance. The material showed that the Belarusian dialect (now a mixture of Belarusian and Russian) helped to preserve words of Baltic origin. The number of words of Baltic origin is scant in those villages where there are Russian-speaking inhabitants and only few Belarusian language features. Interlocutors often highlight
\end{abstract}


that they know a certain word only from their childhood and no-one describes things in that way.

Keywords: words of Baltic origin; mixed Belarusian-Russian dialects; borrowings; Pskov region

Correspondence: Mirosław Jankowiak, Institute of Slavic Studies, Polish Academy of Sciences, Warsaw, e-mail: mirek.jankowiak@gmail.com

Support of the work: This work was supported by a core funding for statutory activities from the Polish Ministry of Science and Higher Education.

Competing interests: The author is a member of the Scientific Board of this journal. 